\title{
Character Education of Muhammadiyah
}

\author{
$1^{\text {st }}$ Nana Sutarna \\ Department of Primary School Teacher \\ Education \\ STKIP Muhammadiyah Kuningan. \\ Indonesia \\ nana@upmk.ac.id \\ $5^{\text {th }}$ Nanang Mulyana \\ Department of Physical Education \\ Health and Recreation, STKIP \\ Muhammadiyah Kuningan \\ Indonesia
}

\author{
$2^{\text {nd }}$ Edo Dwi Cahyo \\ Department of Madrasah Ibtidaiyah \\ Teacher Education \\ IAIN Metro Lampung \\ Indonesia
}

\author{
$3^{\text {rd }}$ Boby Agustan \\ Department of Physical Education \\ Health and Recreation, STKIP \\ Muhammadiyah Kuningan \\ Indonesia
}

\begin{abstract}
This study aims to examine the relevance of character education from the of perspective the teachings of the founder of Muhammadiyah (KH. Ahmad Dahlan) with character values developed by the government (Ministry of Education and Culture). The research approach used is a descriptive qualitative approach to the method of library research. The primary data source is the philosophy of the teachings of KH Ahmad Dahlan, the secondary sources are other books concerned and relevant to research. Analysis of the data used in this study are: Content Analysis Method. The author's findings relate to the question that KH Ahmad Dahlan's character education is found in his seven philosophies and messages, which teaches him to be a visionary human being able to think ahead, namely to be happy in the world and the hereafter. The Relevance of KH Ahmad Dahlan's Character Education with the Ministry of Education and Culture's Character Education Elements, namely, religious character values, honesty, discipline, hard work, creative, independent, democratic, curiosity, national spirit, love of the motherland, respect for achievement, friendship or communicative, peace loving, and fond of reading. As for KH Ahmad Dahlan's character education can support Kemdikbud's character education so as to be able to create effective character education.
\end{abstract}

\section{Keywords-Character, education, Muhammadiyah}

\section{INTRODUCTION}

The issue of national character is now in the spotlight in society. The spotlight was on various aspects of life contained in various writings both in print and electronic media. In addition, experts, community leaders and education observers also discussed the issue of national character lately has begun to fade in the next generation of the nation, various seminar forums, both local, national and international. Cultivating religious values and good morals can be used as an effort to strengthen the character of children. Not only that, the synergy between parenting patterns and educational patterns carried out by schools that are in accordance with the Islamic education system should be carried out in tandem. The Islamic education system, when comprehended as a whole, could make a significant input towards the development of a better education system that is useful for meeting the challenges of today [1]. Next, Haught shows their optimism that problems can be overcome by facing science and religion [2]. The foundation for the integration of science and faith in education is the most fundamental principle in all Islamic teachings: the [3]. Therefore human beings must receive education based on character (wisdom and belief). The first principle of character a good Islamic based is Being Wise and Positive thinking [4].

In order to achieve the ideals of educational character, researchers try to unravel the thoughts that have been offered by the reform figure, KH Ahmad Dahlan, this is intended to try to find solutions to the problems of education in Indonesia today.

$\mathrm{KH}$ Ahmad Dahlan is a type of man of action so that it is in place when leaving a fair amount of charity. Therefore to explore how Ahmad Dahlan's character education concept should refer more to how he built the Islamic education system. Even Parker's findings suggest that: "In Indonesia, Islamic education has become an increasingly popular choice for Indonesian parents over the last decade or more" [5]. With his efforts in the field of education, Ahmad Dahlan can be said as a model of the rise of a generation to answer the challenges facing Islam namely, the lagging of Muslims in the field of education. KH Ahmad Dahlan always thinks of the children of generations in the future so that they can always be a generation of Muslims who have a high fighting value towards Islam.

\section{RESEARCH METHODS}

This study uses a qualitative approach that is research that emphasizes more on the analysis of the deductive and inductive inference process and on the analysis of the dynamics of the relationship between observed 
phenomena using scientific logic. This does not mean that the qualitative approach does not use quantitative data support at all but the emphasis is not on testing but on efforts to answer research questions through formal and argumentative ways of thinking [6].

Qualitative research as a research method has fifteen indicators, namely: (1) the source of the data is a reasonable situation; (2) researchers as research instruments; (3) very descriptive; (4) prioritizing both process and product; (5) searching for the meaning behind behavior; (6) prioritizing direct data; (7) triangulation; (8) accentuates contextual details; (9) the subjects studied are considered to have the same status as the researchers; (10) prioritizing the emic perspective; (11) verification; (12) using an audit trail; (13) participation without disturbing; (14) conduct analysis since the beginning of the study; and (15) research designs appear in the research process.

This research is entirely produced from literature study because this type of research is library research. i.e., researching literature / literature related to the research problem. The primary data sources of this study are 4 books, namely: (1). KH. Ahmad Dahlan Sang Pencerah, Pendidik dan Pendiri Muhammadiyah (Hery Sucipto Best Media Utama, Jakarta, 2010); (2) Marhaenis Muhammadiyah: Ajaran dan Pemikiran KH Ahmad Dahlan (Abdul Munir Mulkhan, Galang Pustaka, Yogyakarta,2013); (3). Biografi Singkat 1869-1923 KH Ahmad Dahlan (Adi Nugroho, Garasi - Ar ruz Media, Yogyakarta, 2018); dan (4) Konsep dan Model Pendidikan Karakter (Muchlas Samani dan Hariyanto, Rosda, Bandung, 2013).

\section{RESULT AND DISCUSSION}

\section{A. Educational Vision KH. Ahmad Dahlan}

$\mathrm{KH}$ Ahmad Dahlan donated his life for education. May the expression not be excessive. If traced from the long history of Ahmad Dahlan's struggle in developing and advancing Muslims from underdevelopment, it was very persistent to fight for his great ideals. According to him, the struggle will succeed when supported by education and propaganda. From here KH Ahmad Dahlan was so excited to make a breakthrough renewal through these two components. He believes that educational institutions are the most strategic media in conveying the ideals of change.

Muhammadiyah, as a new organization (at that time) founded by $\mathrm{KH}$ Ahmad Dahlan faced two different challenges simultaneously namely modernism and traditionalism (explained in the book of Teachings and Thought KH Ahmad Dahlan, Abdul Munir Mulkhan) [7]. Modernism was answered by KH Ahmad Dahlan with the establishment of schools (including HIS met de Qur'an and Schakelschool in Wuluhan), scouting and other voluntaries. Then traditionalism was faced by KH Ahmad Dahlan using tabligh (delivery) by visiting his students, rather than waiting for them to come. Yet at that time, "teachers looking for students" was a socio-cultural disgrace. KH Ahmad Dahlan who became chairman of the Muhammadiyah Hoofdbestuur, a few years later settled in Mecca, relatively old enough, preacher of the Great
Mosque of the Sultanate, members of the Sultanate's religious court, CSI's religious advisor who was actually entitled to become a teacher visited by students. But no, he chose to visit his students.

$\mathrm{KH}$ Ahmad Dahlan's view of education starts from the development of reason through the educational process which will ultimately lead to the growth of creativity and has implications for Muhammadiyah people to have a tajdid (renewal) spirit in Islamic education.

In the Short Biography book 1869-1923 KH Ahmad Dahlan, the work of Adi Nugroho explained the educational philosophy of KH Ahmad Dahlan which was applied in every missionary activity. As an organization of religious renewal, Muhammadiyah is of the view that the key to the progress and prosperity of Muslims is improvement in the field of education. For this reason, the name of this organization has always been taken from the name of the school founded by KH Ahmad Dahlan one year before the founding of Muhammadiyah [8].

B. Perspectives and Concepts of Character Education Based on the Seven Philosophies of KH Ahmad Dahlan

In the book Understanding the Ideology of Muhammadiyah by Dr. H. Haedar Nashir M.Sc., explained that Muhammadiyah as an Islamic movement carries the mission of preaching, experiences the thoughts of da'wah, and takes the methods of preaching, namely bil-hikmah (wise), although mauidhotil hasanah (good education), wajadilhum billati hiya ahsan (best dialogue) [9].

The seven philosophies are the thoughts of KH Ahmad Dahlan written by his student namely KRH.Hadjid. According to history, he was the youngest student of $\mathrm{KH}$ Ahmad Dahlan who was very diligent in recording what was taught by $\mathrm{KH}$ Ahmad Dahlan. In the seven philosophies of KH Ahmad Dahlan, the value of character education is applied by him in teaching his students. These philosophical points are summarized in the book Muqaddimah Philosophy of Doctrine and $\mathrm{KH}$ Ahmad Dahlan, namely:

(a) "We, this human being, live in the world only once, to bet: after death, will we get happiness or misery? And the 'ulama' are in confusion, except for those who practice charity. And those who practice charity are all in concern, except those who are sincere or clean" ; (b) "Most of the people are arrogant, and takbur, they make their own decisions" ; (c) "Man, if he does anything, once, twice, repeatedly, then he becomes ordinary. If it has become a pleasure that is loved, then the habit that is loved is difficult to change. It is natural that most people defend the customs that have been accepted, both from the point of belief or faith, feelings of will and deeds. If anyone will change, they will be able to defend at the expense of body and soul. That is because of his assumption that what is possessed is true" ; (d) "Do you think that most people like to listen or think about finding the right knowledge?" ; (e) Man does not obey, does not care about something that is already bright for him. That is, he himself, hismind own, had said that was true, but he did not want to obey the truth because of fear of hardship, fear of the various 
kinds and concerns, because his lust and heart had already been damaged, diseased (morally), washed away and attracted by bad habits "; (f) "Most people's leaders have not yet dared to sacrifice their property and soul to try to classify humanity in truth. In fact, the leaders are usually just toying with, using humans who are stupid and weak "; and (g) "Learning is divided into two parts: (1) Learning knowledge (knowledge and theory); (2) Learning charity (teaching, practicing). All lessons must be done in a piecemeal, level by level, likewise in the study of charity, it must be level. Even if it doesn't work, it doesn't need to be added "[10].

\section{The Relevance of KH Ahmad Dahlan's Character} Education

As a cleric who is respected by the community because of his intelligence in terms of religion and science, KH Ahmad Dahlan always presents himself as a person who should be emulated by the community. Therefore, he appeared with polite speech and polite behavior in accordance with Islamic teachings. Because according to him, role model is an effective form of education.

\section{Religious Character Value and Tolerance}

$\mathrm{KH}$ Ahmad Dahlan is a very religious person with evidence of establishing an Islamic organization called Muhammadiyah on 8 Dzulhijjah $1330 \mathrm{H}$ or 18 November 1912 AD until it was able to survive for more than a century because the ideological principles of the movement were united in belief, understanding, ideals the dream to live the fertile Islamic movement. The existence of Muhammadiyah as "Islamic Movement, Da'wah Amar ma'ruf nahi munkar and Tajdid 'which was established by $\mathrm{KH}$ Ahmad Dahlan, has always committed to continue to fight for the main mission of" upholding and upholding the Islamic religion so that a true Islamic Community "can be realized. Such is the highest religious attitude of $\mathrm{KH}$ Ahmad Dahlan.

But despite this the fact was discovered that $\mathrm{KH}$ Ahmad Dahlan was very tolerant of the practices of religious his day, so that he could be accepted by all groups. KH Ahmad Dahlan highly respects Christians. This is shown by the very wide association, not limited to fellow Muslims. He was very familiar with priests and priests. Among them were Father Van Lith, Father Van Driessen etc. His association crossed faith and religion. [11].

\section{Honest Character Values}

Behavior carried out in an effort to make himself as a person who can be trusted in the words, actions, and work [12]. The honesty of KH Ahmad Dahlan can be seen when the issue of Qibla direction. When entering the midday prayer, a muezzin of the Great Mosque noticed that there were three white lines that crossed in front of the imam's place from north to south. Three parallel lines with a distance as wide as the prayer in congregation is slightly inclined to the north around 23 degrees. The line seems to give a signal to perform the prayer to congregational follow the line earlier [13].

\section{The Value of Discipline Character}

In the Muhammadiyah movement, KH Ahmad Dahlan is always consistent in thinking, speaking, and working. Thinking with a smart and broad mind with and learning of nobility gives students an understanding of ideology, faith and good character based on the Qur'an and Sunnah. Discipline in religion and obey the commands and prohibitions of Allah SWT [14].

4. The Value of Hard Work Character

view of KH Ahmad Dahlan, Islam cannot be upheld without being fought for through a professional organization. Likewise, to liberate the Indonesian people from the Dutch colonialism, they must improve their knowledge and educational institutions.

5. Creative Character Values Creative

values that are taught are: (1) Teach and spread Islam popularly, not only in pesantren, but also in various places; (2) Changing and correcting the Qibla direction; and (3) The use of astronomical calculations to determine the beginning and end of the fasting month (reckoning) [15].

\section{Independent Character Value}

Around 1908-1909, KH Ahmad Dahlan founded the first formal school, the Madrasah Ibtidaiyah (level elementary school) and Madrasah Diniyah in his home own[16]. The school began with 8 students studying in the living room of KH Ahmad Dahlan's house. He teaches and prepares teaching needs itself, one of which is he uses two of his desks. Meanwhile, the two benches where the students sat were also made from used wooden mori boxes and a blackboard made of suren wood.

\section{The Value of Character of Democracy}

value of democracy shown by KH Ahmad Dahlan can be seen when he is asked by his students what name he will give to the organization he will establish? So he answered: "Muhammadiyah".

8. The Value of Character of Curiosity

KH Ahmad Dahlan studied Qiraah with Sheikh Amin and Sayid Bakri Satock. Furthermore, the kyai also studied medicine and animal poisons from Sheikh Hasan. KH Ahmad Dahlan's vast knowledge, and encompassing high discipline, made $\mathrm{KH}$ Ahmad Dahlan grow into a wise and sharp-thinking person, as well as having a far-sighted outlook. Great curiosity drives KH Ahmad Dahlan, taking advantage of every opportunity to learn.

\section{The National Spirit Character Value}

According to KH. Ahmad Dahlan, to free the Indonesian people from the Dutch colonialism, must increase knowledge and intelligence through educational institutions. He always called on the community to do charity and organize and should stick to the principle "Always accountable for acts of God".

10. The Value of the Character of the Love of the

\section{Motherland}

When the Indonesian nation was still colonized, many people were unable to read and write. This condition made $\mathrm{KH}$ Ahmad Dahlan establish schools for the people in demanding general knowledge and religion. In addition, polyclinics and orphanages were established as well as many, educating young people to hope for the nation. 
State pole women and state apparatus such as civil service, and police with practical religious knowledge and general science. Although the field of struggle in the social and educational fields, but the efforts of KH Ahmad Dahlan has the meaning of a deep care for the environment.

Muhammadiyah is closely connected with the struggle for Indonesian nationality. Where since the establishment of the Muhammadiyah Association in 1912, there have been many services of this organization to the Indonesian people and homeland. Specifically, Ir. Sukarno gave a high appreciation of the role of KH.Ahmad Dahlan in pioneering the idea of nationalism. The first president of the Republic of Indonesia mentioned KH Ahmad Dahlan as one of the influential figures in the struggle for intellectualism in Indonesia.

\section{Character Value Appreciating Achievement of the}

Foundation KH Ahmad Dahlan in adopting a form of education from outside, was inspired by the teachings of the Prophet, "Should learn the language of your enemy so as not be deceived by your enemy". As well as the words of the Prophet: "Demand knowledge to the land of China". This is the background of KH.Ahmad Dahlan to establish a school that uses Dutch. Another example can be seen from his support for women in getting an education, "why most of you if you are sick go to a doctor male, especially if you have children. If you are truly ashamed, continue to study, make yourself a doctor, so that we already have a doctor femalefor women too "[17].

\section{Value of Friendly / Communicative Character}

At the end of 1897, KH Ahmad Dahlan felt the need to continue his ideals with a wider reach. He planned to hold a deliberation among the religious scholars, both inside and outside the city of Yogyakarta, to determine the inaccurate direction of the Qibla (Wibowo, 2012: 97).

\section{The Value of the Characters of Peace of Love}

In the face of trials and obstacles, KH Ahmad Dahlan did not tremble or step down. His heart is also more determined to read, to continue his ideals and struggle. So that Muhammadiyah is able to expand its wings to various regions in Indonesia. This shows that he always loved peace with others, even though in establishing Muhammadiyah he received insults, curses,insults, he remained steadfast and patiently faced them.

\section{Character Value Reading Fondness}

At the age of eight years $\mathrm{KH}$ Ahmad Dahlan has fluently read the Koran to the end teacher As a religious, he has many books that are used to be studied in huts.

\section{CONCLUSION}

KH Ahmad Dahlan's concept of character education is right and wrong, good and bad that is determined by law that is legitimate and sacred in the eyes of Islam in accordance with the Qur'an and the US-Sunnah. KH Ahmad Dahlan's basic character education is prioritized with Islamic education which consists of 3 cases namely faith, science and charity. KH Ahmad Dahlan's character education is also found in seven core philosophies and his will messages while teaching. His character education is implemented by instilling character in his students through moral education in accordance with the Qur'an and asSunnah so that it can produce students who have Islamicbased character. The Relevance of the Ministry of National Education's Character Education Values with KH Ahmad Dahlan's Perspective Character Education including the values of religious character, honest, discipline, hard work, creative, independent, democratic, curiosity, national spirit, love of the motherland, respect for achievement, friendship or communicative, love peace, and love to read. As for KH Ahmad Dahlan's character education can support the Ministry of Education and Culture's character education so as to be able to create effective character education.

\section{ACKNOWLEDGMENTS}

To the PP Muhammadiyah Diktilitbang Assembly for providing grants through the Muhammadiyah Research Grant scheme so as to facilitate the preparation of this research, all elements of the leadership of STKIP Muhammadiyah Kuningan, parties who have assisted in writing this scientific paper and also reviewers and editor of proceedings this, so we can publish this topic.

\section{REFERENCES}

[1] Dzilo, H. 2012. The concept of "Islamization of knowledge" and its philosophical implications. Islam and Christian-Muslim Relations, 23, 247-256.

[2] Haught, John F. 2004. Perjumpaan Sains dan Agama : Dari Konflik ke Dialog. Bandung: Mizan Pustaka. ISBN : 979-433-371-9.

[3]. Kartanegara, Mulyadi. 2005. Integerasi Ilmu : Sebuah Rekontruksi Holistik. Bandung: Arasy Mizan Pustaka. ISBN 979-3551-11-9.

[4] Susanto. 2017. Islamic Character - Based Education to Improve Students' Learning. Advances in Social Science, Education and Humanities Research (ASSEHR), volume 109. 4th Asia Pacific Education Conference (AECON 2017).

[5] Parker, Lyn \& nillan, Pan. 2013. Adolescent in Contemporary Indonesia. Routledge: Third Avenue, New York, NY.

[6] Azwar, Saifuddin. 2010. Metode Penelitian. Yogyakarta: Pustaka Pelajar.

[7] Mulkhan, Abdul Munir. 2013. Marhaenis Muhammadiyah: Ajaran dan Pemikiran KH Ahmad Dahlan. Yogyakarta: Galang Pustaka

[8] Nugroho, Adi. 2018. Biografi Singkat 1869-1923 KH Ahmad Dahlan. Yogyakarta: Garasi

[9] Nashir, Haedar. 2014. Memahami Ideologi Muhammadiyah. Yogyakarta: Suara Muhammadiyah

[10] Hadjid, K.R.H. 2008. Pelajaran K.H. Ahmad Dahlan, 7 Falsafah \& 17 ayat Al-Qur'an. Yogyakarta: LPI PP Muhammadiyah

[11] Asrofie, M. Yusron. 1983. K.H. Ahmad Dahlan: Pemikiran dan Kepemimpinannya. Yogyakarta: Yogyakarta Offset

[12] Sutarna, Nana. 2018. Pendidikan Karakter Siswa Sekolah Dasar dalam Perspektif Islam. Yogyakarta: Putaka Diniyah.

[13] Wibowo, Agus. 2012. Pendidikan Karakter: Startegi Membangun Karakter Bangsa Berperadaban.Yogyakarta: Pustaka Belajar

[14] Sucipto, Hery. 2010. KH. Ahmad Dahlan: Sang Pencerah, Pendidikan, dan Pendiri Muhammadiyah. Jakarta: Best Media Utama

[15] Anshory, HM Nasrudin. 2010. Matahari Pembaharuan Rekam Jejak KH. Ahmad Dahlan. Yogyakarta: Galangpess

[16] Mulkhan, Abdul Munir. 1990. Pemikiran KH Ahmad Dahlan dan Muhammadiyah. Jakarta: Bumi Aksara

[17] Salam, Yunus. 1986. KH. A Dahlan Pemikir dan Kepemimpinannya. Jakarta: Depot Pengajaran Muhammadiyah 